\title{
In Vitro Study of Cytotoxicity of Orthodontic Elastomeric Ligatures
}

\author{
Rogério Lacerda dos Santos ${ }^{\mathrm{a} *}$, Matheus Melo Pithon ${ }^{\mathrm{b}}$, Paulyana Pryscilla de Melo Freire ${ }^{\mathrm{a}}$,
}

\author{
Maria Teresa Villela Romanos ${ }^{c}$
}

\begin{abstract}
${ }^{a}$ Department of Orthodontics, Federal University of Campina Grande - UFCG, Av. dos Universitários, s/n, Rod. Patos/Teixeira, Km 1, Santa Cecília, CEP 58700-970, Patos, PB, Brazil

${ }^{\mathrm{b}}$ Department of Orthodontics, State University of Sudoeste da Bahia - UESB, Centro Odontomédico, Dr. Altamirando da Costa Lima, Av. Otávio Santos, 395, Sala 705, Vitória da Conquista, BA, Brazil

'Department of Virology, Federal University of Rio de Janeiro - UFRJ, Av. Professor Rodolpho Paulo Rocco, 325, CEP 21941-617, Ilha do Fundão, Rio de Janeiro, RJ, Brazil
\end{abstract}

Received: September 30, 2011; Revised: May 9, 2012

This study investigated the cytotoxicity of crystal-coloured orthodontic elastomeric ligatures of polyurethane. Six ligatures from distinct manufactures were divided into 6 groups of 10 elastics each: Groups P1, P2, P3, P4, P5 and P6 (Polyurethane). The cytotoxicity essay was performed using L-929 line cells, which were submitted to the cell viability test with neutral red ("dye-uptake") at time intervals of 1, 2, 3, 7 and 28 days. Analysis of variance (ANOVA) with multiple comparisons and Tukey's test were used $(\mathrm{p}<.05)$. There were statistical differences $(\mathrm{p}<.05)$ in cell viability between Groups P1, P4, P2 and P3, and Groups P5 and P6 at 1 and 2 days. All elastomeric ligatures were considered suitable for clinical use. The hypothesis was accepted, the P5 and P6 elastomers and the processing route of injection molding for these ligatures showed the lowest cell viability, due the temperature and pressure distinct in the processing of these elastomers.

Keywords: cytotoxicity, elastomers, cell culture, orthodontics

\section{Introduction}

Latex elastics are commonly used in orthodontic treatment, however, the protein content of latex is a known allergen. Allergy caused by latex proteins, including immediate hypersensitivity reactions ${ }^{1,2}$, has been well documented ${ }^{1}$, and the prevalence of latex allergy has been reported to be between $3 \%$ and $17 \%$. Moreover, professionals and patients are at greater risk of hypersensitivity reactions ${ }^{5}$.

The production of prevulcanized latex involves mixing natural rubber latex with stabilizers and vulcanizing chemical $^{2,5}$. The process adds some potentially toxic compounds. Stabilizers and cross-linking agents such as zinc oxide, dialkyldithiocarbamate (DTC) accelerators, and sulfur are added to the natural rubber latex during manufacture ${ }^{5}$.

As an alternative to latex, different types and compositions of elastomers, such as polyurethane and silicone elastics have been launched on the market, in order to decrease the risk of allergic reactions caused by latex orthodontic elastics. Among these reactions ${ }^{2}$, swelling and stomatitis, erythematous oral lesions, respiratory reactions, and even anaphylactic shock, the most severe form of allergy ${ }^{3}$, can be cited.

But little is known about the possibility of polyurethane orthodontic ligatures being cytotoxic to oral mucosal cells $^{1-7}$. Cell lines ${ }^{8}$, such as L 929 mouse fibroblasts ${ }^{9}$, have been shown to behave similarly to primary human gingival

*e-mail: lacerdaorto@ hotmail.com fibroblasts, and therefore, are a suitable in vitro model to test the toxicity ${ }^{10-13}$ of products used intra-orally during orthodontic treatment ${ }^{14-16}$. Given the hypothesis that there is a difference in cytotoxicity between manufacturers different elastics, the objective of the present in vitro study was to test the cytotoxicity of polyurethane Orthodontic elastomeric ligatures.

\section{Material and Methods}

Crystal-coloured orthodontic elastomeric ligatures (polyurethane) from 6 different manufacturers (modular type) were selected for cytotoxicity study (Table 1 ). The samples were divided into 6 groups of 10 elastics each: Group P1 (3M Unitek, Monrovia, California, USA), Group P2 (TP Orthodontics, Lodi, California, USA), Group P3 (American Orthodontics, Sheboygan, Wisconsin, USA), Group P4 (GAC International, Bohemia, New York, USA), Group P5 (Morelli, Sorocaba, São Paulo, Brazil) and Group P6 (Tecnident, São Carlos, São Paulo, Brazil). All samples had recent manufacturing dates, were from the same production lot and came in sealed plastic packages. The powder coating of the elastomeric ligatures was removed. The elastics were washed for 15 seconds with deionized water by using a Milli-Q purification system (Millipore, Bedford, MA, USA). Before testing all elastomeric ligatures were sterilized by exposure to ultraviolet light (Labconco, Kansas, Missouri, USA) for 30 minutes $^{17-18}$. 
Table 1. Experimental and control groups used for the assays.

\begin{tabular}{ccccc}
\hline Groups & Trademark & Main Composition & Color & Reference number \\
\hline P1 & Unitek & Polytetramethylene ether glycol & crystal & $406-870$ \\
P2 & TP Orthodontics & Polytetramethylene ether glycol & crystal & $383-921$ \\
P3 & American Orthodontics & Polytetramethylene ether glycol & crystal & $854-279$ \\
P4 & GAC & Polytetramethylene ether glycol & crystal & $59-650-70$ \\
P5 & Morelli & Polytetramethylene ether glycol & crystal & $60-06-100$ \\
P6 & Tecnident & Polytetramethylene ether glycol & crystal & $407-001$ \\
C+ & \multicolumn{2}{c}{ Tween 80 (Polyoxyethylene-20-sorbitan, Sigma, St. Louis, Missouri, USA) } \\
C- & \multicolumn{4}{c}{ PBS solution (phosphate-buffered saline, Cultilab, Campinas, São Paulo, Brazil) } \\
\hline \multicolumn{5}{c}{}
\end{tabular}

The cell culture model used was the monolayer containing L-929 line cells (American Type Culture Collection - ATCC, Rockville, MD, USA) was maintained in Eagle's minimum essential medium (Cultilab, Campinas, Brazil) by adding $0.03 \mathrm{mg} \cdot \mathrm{mL}^{-1}$ of glutamine, $50 \mu \mathrm{g} . \mathrm{mL}^{-1}$ of garamicine, $2.5 \mu \mathrm{g} \cdot \mathrm{mL}^{-1}$ of fungizone, $0.25 \%$ sodium bicarbonate solution, $10 \mathrm{mM}$ of HEPES, and $10 \%$ bovine fetal serum for growth medium. Next, the cell culture medium was incubated at $37^{\circ} \mathrm{C}$ for 48 hours.

To verify the cell response in extreme situations, three additional groups were included in the study: Group CC (cell control), consisting of L-929 cells not exposed to supernatants from the elastomeric ligatures; Group C+ (positive control), consisting of Tween 80 (Polyoxyethylene-20-sorbitan, Sigma, St. Louis, Missouri, USA); Group C- (negative control), consisting of phosphate-buffered saline (PBS) solution (Table 1). The positive and negative controls were incubated in MEM maintenance medium (Eagle's minimum essential medium) for 1, 2, 3, 7 and 28 days and the extracted elutes were added to L-929 line cells incubated in the growth medium.

The cytotoxicity of these orthodontic elastics was determined by means of the dye-uptake technique ${ }^{19}$, which is based on the neutral red absorption by living cells. Because these elastomeric ligatures are usually maintained in the oral cavity for up to 4 weeks, since patients wearing fixed appliances usually visit the orthodontist once a month. Different periods of time were considered: $1,2,3,7$, and 28 days. These experimental periods represent the time intervals during which elastomeric ligatures were kept under cell culture conditions before being removed from them.

\subsection{Dye-uptake}

Volumes of $100 \mu \mathrm{L}$ of L-929 cells were distributed into 96-well microplates. After 48 hours, the growth medium was replaced with $100 \mu \mathrm{L}$ of Eagle's minimum essential medium (MEM) obtained after incubation in the different types of elastomeric ligatures for time intervals of 1, 2, 3, 7 and 28 days. Eagle's minimum essential medium was used because it is the same type of material used for cell maintenance, thus not influencing the results.

After 24 hours incubation, $100 \mu \mathrm{L}$ of 0.01 per cent neutral red dye (Sigma, St. Louis, Missouri, USA) was added to each well in the microplates and incubated for 3 hours at $37{ }^{\circ} \mathrm{C}$. After this time interval, $100 \mu \mathrm{L}$ of 4 per cent formaldehyde solution in PBS (130 mmol of NaCl; $2 \mathrm{mmol}$ of $\mathrm{KCl} ; 6 \mathrm{mmol}$ of $\mathrm{Na}_{2} \mathrm{HPO}_{4} 2 \mathrm{H}_{2} \mathrm{O} ; 1 \mathrm{mmol}$ of $\mathrm{K}_{2} \mathrm{HPO}_{4}$
$1 \mathrm{mmol} ; \mathrm{pH}$ 7.2) were added to each well to promote cell attachment to the plate. After 5 minutes, $100 \mu \mathrm{L}$ of $1 \%$ acetic acid and $50 \%$ methanol were added in order to remove the dye not taken up by the cells. After 20 minutes, a spectrophotometer (BioTek, Winooski, Vermont) set at a wavelength of $492 \mathrm{~nm}$ was used to determine the dye taken up by the cells. Because elastomeric ligatures can be in the oral cavity for up to 4 weeks, cell viability was determined after exposure to MEM in which the elastics had been incubated for 1, 2, 3, 7 and 28 days. The cytotoxicity of the materials was determined according to the ISO 10993-5 standard for evaluation and standardization.

For ranking the cytoxicity, a post hoc comparison was performed $^{20-21}$. Statistical calculations were performed with 1-way analysis of variance (ANOVA) followed by the Tukey post hoc test. $P$-values lower than 0.05 were considered to indicate significant differences. Each culture well was considered an individual sample.

\section{Results}

There was statistically significant difference $(\mathrm{p}<.05)$ between the viability of the cells in Group CC (Figure 1a) and all other groups at 1,2, 3, 7 and 28 days. In addition, there were no statistically significant differences between the viability of the cells in Groups P1, P4, P2 (Figure 1b) and P3, or between Groups P5 and P6 (Figure 1c) at 1 and 2 days; between Groups P1, P4, P2, P3 and P5 at 3 days; or Groups P1, P4, P2, P3 and P6 at 7 days; or Groups P1, P4, P2 and P3; or Groups P4, P2, P5 and P6 at 28 days (Table 2 and Figure 2). At 1 and 2 days, there was a reduction in viable cells in all the Groups, in comparison with the other experimental time intervals (Table 2 and Figure 2).

At 24 hours the percentage of viable cells varied between 91.0\% in Group P3 to 80.3\% in Group P6 for elastomeric ligatures. These percentages of viable cells decreased slightly over the following 24 hours in all Groups. After this there was a continual increase in all Groups between days 3 and 28 .

\section{Discussion}

The cell culture model used in the present study was the monolayer type ${ }^{22}$. This model was used together with the dye-uptake technique ${ }^{19}$ because the cytotoxicity of materials can be determined by spectrophotometry.

Spectrophotometric essay allows rapid and reliable evidence of cell viability to be obtained based on the use 


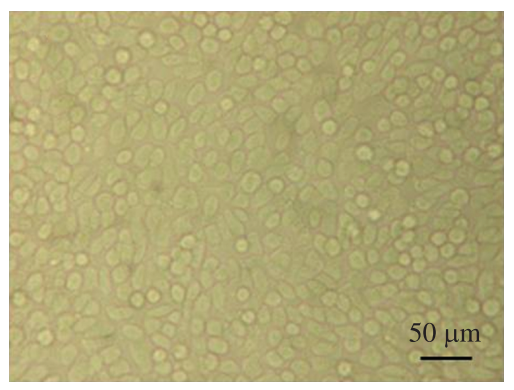

(a)

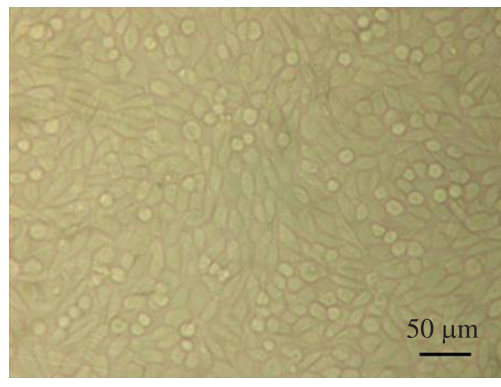

(b)

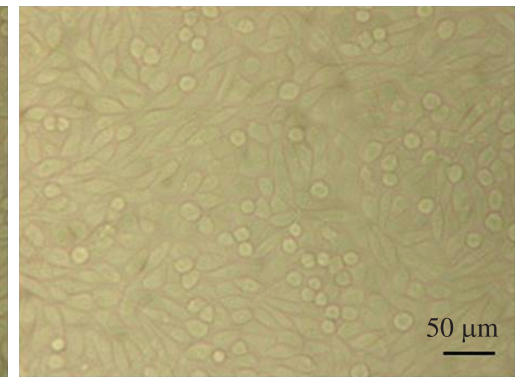

(c)

Figure 1. Cell aspect. a) cell control; b) Group P2 (TP Orthodontics) at 2 days; c) Group P6 (Tecnident) at 2 days. Bar $=50 \mu \mathrm{m}$.

Table 2. Descriptive statistics for optical density of elastomeric ligatures at 1 to 28 days.

\begin{tabular}{|c|c|c|c|c|c|c|c|c|c|c|c|c|c|c|c|}
\hline \multirow[b]{2}{*}{ Groups } & \multicolumn{6}{|c|}{ Time (2 days) } & \multicolumn{3}{|c|}{ Time (3 days) } & \multicolumn{3}{|c|}{ Time (7 days) } & \multicolumn{3}{|c|}{ Time (28 days) } \\
\hline & $\mathbf{M}$ & SD & $\begin{array}{l}\text { VC } \\
(\%)\end{array}$ & M & SD & $\begin{array}{l}\mathrm{VC} \\
(\%)\end{array}$ & $\mathbf{M}$ & SD & $\begin{array}{l}\mathrm{VC} \\
(\%)\end{array}$ & $\mathbf{M}$ & SD & $\begin{array}{l}\mathrm{VC} \\
(\%)\end{array}$ & $\mathbf{M}$ & SD & $\begin{array}{l}\mathrm{VC} \\
(\%)\end{array}$ \\
\hline $\mathrm{CC}$ & $.651 \mathrm{a}$ & .045 & 100.0 & $.718 \mathrm{a}$ & .029 & 100.0 & $.790 \mathrm{a}$ & .044 & 100.0 & $.632 \mathrm{a}$ & .036 & 100.0 & $.910 \mathrm{a}$ & .038 & 100.0 \\
\hline $\mathrm{C}-$ & .639 & .041 & 98.3 & .696 & .047 & 97.0 & .763 & .044 & 96.6 & .603 & .022 & 95.5 & .862 & .039 & 94.8 \\
\hline $\mathrm{C}+$ & .064 & .009 & 9.90 & .058 & .010 & 8.10 & .077 & .010 & 9.80 & .055 & .008 & 8.80 & .102 & .009 & 11.3 \\
\hline $\mathrm{P} 1$ & $.580 \mathrm{~b}$ & .031 & 89.2 & $.626 \mathrm{~b}$ & .035 & 87.3 & $.726 b$ & .037 & 92.0 & $.591 \mathrm{~b}$ & .027 & 93.6 & $.855 b$ & .045 & 94.0 \\
\hline $\mathrm{P} 2$ & $.575 b$ & .040 & 88.4 & $.618 b$ & .038 & 86.1 & $.744 b$ & .041 & 94.3 & $.587 \mathrm{~b}$ & .027 & 93.0 & $.847 \mathrm{bc}$ & .044 & 93.1 \\
\hline P3 & $.592 \mathrm{~b}$ & .038 & 91.0 & $.644 b$ & .044 & 89.7 & $.727 b$ & .045 & 92.1 & $.597 \mathrm{~b}$ & .039 & 94.5 & $.855 b$ & .049 & 94.0 \\
\hline P4 & $.591 b$ & .032 & 90.8 & $.642 b$ & .035 & 89.5 & $.726 b$ & .047 & 91.9 & $.575 b$ & .029 & 91.1 & $.839 b c$ & .025 & 92.2 \\
\hline P5 & $.547 \mathrm{c}$ & .038 & 84.1 & $.575 c$ & .043 & 80.2 & $.721 b$ & .037 & 91.3 & $.544 \mathrm{c}$ & .047 & 86.1 & $.829 c$ & .033 & 91.1 \\
\hline P6 & $.522 \mathrm{c}$ & .037 & 80.3 & $.560 \mathrm{c}$ & .035 & 78.0 & $.680 \mathrm{c}$ & .040 & 86.1 & $.576 b$ & .048 & 91.2 & $.833 \mathrm{c}$ & .034 & 91.6 \\
\hline
\end{tabular}

$\mathrm{N}=10$. Analysis of variance ANOVA and Tukey's test were employed $(\mathrm{p}<0.05)$. Values followed by same letters are not significantly different $(\mathrm{p}>0.05)$ for the same time. M: Mean. SD: standard deviation. VC: Viable Cells.

of vital stain incorporated by viable cells ${ }^{23-26}$. In this study, neutral red dye was used, as it is widely used for identifying L-929 cell viability ${ }^{23,25-26}$. Dead or damaged cells cannot incorporate vital stain, and are thus not recognized on optical reading. Therefore, spectrophotometry does not allow dead cells to be distinguished from the damaged ones ${ }^{23}$.

L-929 mouse fibroblasts were used because they provide results comparable with those of primary human gingival fibroblasts ${ }^{14-15}$, however, one cannot interpret the cell culture $^{13}$ results as a human response.

The percentage of viable cells was obtained by comparing the mean optical density (OD) in the control group (cells with no contact with elastomeric ligatures) with that obtained from supernatants of cell cultures that had been in contact with elastomeric ligatures ${ }^{18,25}$.

As sterilization is a prerequisite for cytotoxicity essays, ultraviolet radiation ${ }^{17-18}$ was performed on each elastic surface used in this study for 30 minutes. It was observed that all elastics exhibited the same color aspect and malleability after sterilization with UV light.

Because natural latex rubber has increasingly been used as dental material, many cytotoxicity issues have been reported. $1^{6}$. Conservants such as sulphur and zinc oxide as well as antioxidants such as di-thio-carbohydrates, $\mathrm{N}$-nitrosodibutylamine, and $\mathrm{N}$-nitrosopiperidine are all known to be cytotoxic substances ${ }^{7}$. Holmes et al. ${ }^{27}$ verified whether the coloring agents used in the fabrication of coloured latex could have some toxic effect. Their results showed that these coloring agents exhibited low toxicity, however, this effect is clinically harmless.
In view of reports of latex allergy in the literature ${ }^{28-29}$, this study evaluated the cytotoxicity of latex-free materials used as an alternative to latex, such as polyurethane Orthodontic elastomeric ligatures, as crystal-colored elastomeric ligatures are used with metal appliances, this being the most applicable color for esthetic appliances.

Allergy to natural latex occurs because of the presence of many types of proteins, and the powder covering orthodontic elastics works as a vehicle for these proteins. Therefore, the development of non-latex elastics for clinical use has become increasingly important.

Elastics derivatives of polyurethanes, are thermoplastic polymers processed currently by injection molding and by sintering. After the chemical reactions of polymerization that the originate, appear as amorphous masses, whose polymerics chains have relatively weak traction forces between them and chemical bonds randomly located along these chains ${ }^{30}$. To improve its mechanical properties, must occur to union between the side chains through cross covalently bonds using the process known as vulcanization. Thus, three-dimensional structures are formed converting a flexible product in an resistant highly material, but elastic $^{30}$. In this study, the P5 and P6 elastomeric ligatures demonstrated to be more malleable than the ligatures others, result of a different curing process.

P1, P2, P3 and P4 were assessed on the biological properties, and it was observed that these materials induced a smaller amount of cell lysis compared with the other polyurethane elastomeric ligatures. As the powder covering the elastomeric ligatures of all manufacturers was removed 




Figure 2. Percentage viability of tested elastomeric ligatures obtained by spectrophotometry.

before performing the in vitro studies, it was not possible to know whether this powder would have had any effect. The powder was removed in order to standardize the samples as regards composition and the quantity of powder present on the elastomeric ligatures could interfere with the results.

According to $\mathrm{Schmalz}^{16}$, the great danger is that potentially cytotoxic intra-oral elastics could release substances that might be ingested by the patient over time, thus causing diseases resulting from a cumulative effect.

Evidence of this cytotoxic feature was shown after the elastomeric ligatures were exposed to a cell culture medium. The P5 and P6 elastomeric ligatures induced a greater amount of cell lysis at 24 and 48 hours, suggesting a greater release of toxic ingredients at 48 hours, due the possibility of polyurethane degradation and release of cytotoxic components, which was shown on days 1 and 2, and decreased on days 3, 7 and 28. This showed that the release of cytotoxic components is neither constant nor continuing.

Huget et al. ${ }^{31}$ reported that exposure of the elastomer in water leads to a weakening of the intermolecular forces and hence a chemistry degradation. Thus, such condition may influence biological properties of these materials, as the cell viability evaluated in this study.

The better performance of the other groups in comparison with P5 and P6 elastomeric ligatures, suggesting that different processes in the manufacture of the ligatures lead to their different cytotoxic characteristics, although they are made of the same type of material - base, the polytetramethylene ether glycol.

P1, P2 and P3 Orthodontics elastomeric ligatures showed low a capacity of inducing cell lysis irrespective of the time interval evaluated. The elastomeric ligatures evaluated in this study showed over $80 \%$ cell viability regardless of the experimental time interval, except for the P6 elastomeric ligatures at day 2. In the study conducted by Hanson et al. ${ }^{32}$, who evaluated 3/16-inch latex and non-latex interior lumen (medium) elastics, the presence of cell lysis was found to be $50 \%$ higher for latex elastics in comparison with the non-latex types. However, the authors considered both types of elastics appropriate for orthodontic use. Therefore, it is suggested that elastics with cell viability less than $50 \%$ should be avoided in order to prevent cumulative effects of the cytotoxic components released into the body by these elastics ${ }^{16}$. Thus, all the elastomeric ligatures assessed in this study may be considered clinically biocompatible.

There seems to be an important relationship between the manufacturing process of these ligatures and their cytotoxic nature. The quality of elastomeric ligatures is defined by the degree of technology used, the refinement of the technique of production and the quality of raw materials used during manufacture of material ${ }^{30}$.

As these materials are widely used in clinical orthodontics, care should be taken as regards the cytotoxicity of orthodontic elastomeric ligatures, particularly with regard to ligatures as they are in very close contact with gingiva. It should be pointed out that the use of elastomers in patients with gingival hyperplasia and/or potential periodontal problems must be of the type with the lowest cytotoxic nature, or preferably metal ligatures ${ }^{33}$.

\section{Conclusion}

The hypothesis was accepted, the P5 and P6 elastomers and the processing route of injection molding for these ligatures showed the lowest cell viability, due the temperature and pressure distinct in the processing of these elastomers. However, this is an in-vitro study and clinical interpretations need to be made with caution.

\section{References}

1. Palosuo T, Alenius H and Turjanmaa K. Quantitation of latex allergens. Methods. 2002; 27:52-58. http://dx.doi.org/10.1016/ S1046-2023(02)00051-8

2. Wakelin SH and White IR. Natural rubber latex allergy. Clinical and Experimental Dermatology. 1999; 24:245-248. PMid: 10457121 . http://dx.doi.org/10.1046/ j.1365-2230.1999.00470.x 
3. Tomazic VJ, Withrow TJ, Fisher BR and Dillard SF. Latex-associated allergies and anaphylactic reactions. Clin Immunol Immunopathol. 1992; 64:89-97. http://dx.doi. org/10.1016/0090-1229(92)90185-Q

4. Turjanmaa K, Alenius H, Makinen-Kiljunen S, Reunala T and Palosuo T. Natural rubber latex allergy. Allergy. 1996; 51:593602. PMid:8899110.

5. Perrella FW and Gaspari AA. Natural rubber latex protein reduction with an emphasis on enzyme treatment. Methods. 2002; 27:77-86. http://dx.doi.org/10.1016/ S1046-2023(02)00055-5

6. Fiddler W, Pensabene J, Sphon J and Andrzejewski D. Nitrosamines in rubber bands used for orthodontic purposes. Food and Chemical Toxicology. 1992; 30:325-326. http:// dx.doi.org/10.1016/0278-6915(92)90010-I

7. Hwang $\mathrm{CJ}$ and Cha JY. Mechanical and biological comparison of latex and silicone rubber bands. American Journal of Orthodontics and Dentofacial Orthopedics. 2003; 124:379-386. http://dx.doi.org/10.1016/S0889-5406(03)00564-X

8. Lessa FCR, Aranha AMF, Hebling J and Costa CAS. Cytotoxic effects of White- TA and MTA-Bio cements on odontoblast-like cells (MDPC-23). Brazilian Dental Journal. 2010; 21:2431. PMid:20464317. http://dx.doi.org/10.1590/S010364402010000100004

9. Miranda RB, Fidel SR and Boller MA. L929 cell response to root perforation repair cements: an in vitro cytotoxicity assay. Brazilian Dental Journal. 2009; 20:22-26. PMid:19466226. http://dx.doi.org/10.1590/S0103-64402009000100003

10. D'Anto V, Spagnuolo G, Schweikl H, Rengo S, Ambrosio L, Martina $\mathrm{R}$ et al. Effect of N-acetyl cysteine on orthodontic primers cytotoxicity. Dental Materials. 2011; 27:180-186. PMid:21081246. http://dx.doi.org/10.1016/j. dental.2010.10.011

11. Hafez HS, Selim EM, Kamel Eid FH, Tawfik WA, Al-Ashkar EA and Mostafa YA. Cytotoxicity, genotoxicity, and metal release in patients with fixed orthodontic appliances: A longitudinal in-vivo study. American Journal of Orthodontics and Dentofacial Orthopedics. 2011; 140:298-308. PMid:21889074. http://dx.doi.org/10.1016/j.ajodo.2010.05.025

12. Limberger KM, Westphalen GH, Menezes LM, Medina-Silva R. Cytotoxicity of orthodontic materials assessed by survival tests in Saccharomyces cerevisiae. Dental Materials. 2011; 27:e81-86. PMid:21376384. http://dx.doi. org/10.1016/j.dental.2011.01.001

13. Yeap SK, Omar AR, Ali AM, Ho WY, Beh BK and Alitheen NB. Immunomodulatory effect of rhaphidophora korthalsii on natural killer cell cytotoxicity. Evidence-Based Complementary and Alternative Medicine. 2012; 2012:786487.

14. Schedle A, Samorapoompichit P, Rausch-Fan XH, Franz A, Fureder W, Sperr WR et al. Response of L-929 fibroblasts, human gingival fibroblasts, and human tissue mast cells to various metal cations. Journal of Dental Research. 1995; 74:15131520. PMid:7560408. http://dx.doi.org/10.1177/002203459 50740081301

15. Franz A, Konig F, Skolka A, Sperr W, Bauer P, Lucas T et al. Cytotoxicity of resin composites as a function of interface area. Dental Materials. 2007; 23:1438-1446. PMid:17688932. http:// dx.doi.org/10.1016/j.dental.2007.05.014

16. Schmalz G. Use of cell cultures for toxicity testing of dental materials - advantages and limitations. Journal of Dentistry. 1994; 22 Suppl 2:S6-11. http://dx.doi. org/10.1016/0300-5712(94)90032-9

17. Santos RL, Pithon MM, Mendes GS, Romanos MTV and Ruellas ACO. Cytotoxicity of intermaxillary orthodontic elastics of different colors: An in vitro study. Journal of Applied
Oral Science. 2009; 4:326-329. PMid:19668992. http://dx.doi. org/10.1590/S1678-77572009000400010

18. Dos Santos RL, Pithon MM, Martins FO, Romanos MT and De Oliveira Ruellas AC. Evaluation of the cytotoxicity of latex and non-latex orthodontic separating elastics. Orthodontics and Craniofacial Research. 2010; 13:28-33. http://dx.doi. org/10.1111/j.1601-6343.2009.01469.x

19. Neyndorff HC, Bartel DL, Tufaro F and Levy JG. Development of a model to demonstrate photosensitizer-mediated viral inactivation in blood. Transfusion. 1990; 30:485-490. PMid:2165643. http://dx.doi.org/10.1046/ j.1537-2995.1990.30690333476.x

20. Einot I and Gabriel KR. A study of powers of several methods of multiple comparisons. Journal of the American Statistical Association. 1975; 70:574-583.

21. Welsch RE. Stepwise multiple comparison procedures. Journal of the American Statistical Association. 1977; 72:359-366.

22. Tomakidi P, Koke U, Kern R, Erdinger L, Kruger H, Kohl A et al. Assessment of acute cyto- and genotoxicity of corrosion eluates obtained from orthodontic materials using monolayer cultures of immortalized human gingival keratinocytes. Journal of Orofacial Orthopedics. 2000; 61:2-19. http://dx.doi. org/10.1007/BF02340928

23. Pithon MM, dos Santos RL, Martins FO, Romanos MT and Araujo MT. Cytotoxicity of orthodontic separating elastics. Australian Orthodontic Journal. 2010; 26:16-20. PMid:20575194.

24. Santos RL, Pithon MM, Oliveira MV, Mendes GS, Romanos AC and Ruellas ACO. Cytotoxicity of intraoral orthodontic elastics. Brazilian Journal Of Oral Sciences. 2008; 24:1520-1525.

25. Dos Santos RL, Pithon MM, Martins FO, Romanos MT and Ruellas AC. Evaluation of cytotoxicity and degree of conversion of glass ionomer cements reinforced with resin. The European Journal of Orthodontics. 2011; 2011:21478300.

26. Pithon MM, Santos RL, Martins FO, Romanos MTV and Araújo MTS. Evaluation of Cytotoxicity and Degree of Conversion of Orthodontic Adhesives over Different Time Periods. Materials Research. 2010; 13:165-169. http://dx.doi. org/10.1590/S1516-14392010000200008

27. Holmes J, Barker MK, Walley EK and Tuncay OC. Cytotoxicity of orthodontic elastics. American Journal of Orthodontics and Dentofacial Orthopedics. 1993; 104:188-191. http://dx.doi. org/10.1016/S0889-5406(05)81009-1

28. Snyder HA and Settle S. The rise in latex allergy: implications for the dentist. Journal of the American Dental Association. 1994; 125:1089-1097. PMid:8064050.

29. Neiburger EJ. A case of possible latex allergy. Journal of Clinical Orthodontics. 1991; 25:559-560. PMid:1816265.

30. Morton M. Rubber Technology. 3rd ed. Londres: Chapman \& Hall; 1995.638 p.

31. Huget EF, Patrik KS and Nunez LJ. Observations on the elastic behavior of synthetic orthodontic elastomer. Journal of Dental Research.1990; 69:496-501. PMid:2307753. http://dx.doi.org/ 10.1177/00220345900690021601

32. Hanson $M$ and Lobner D. In vitro neuronal cytotoxicity of latex and nonlatex orthodontic elastics. American Journal of Orthodontics and Dentofacial Orthopedics. 2004; 126:65-70. PMid:15224061. http://dx.doi.org/10.1016/j.ajodo.2003.07.006

33. Santos RL, Pithon MM and Romanos MT. The influence of $\mathrm{pH}$ levels on mechanical and biological properties of nonlatex and latex elastics. Angle Orthodontist. 2011. 